\title{
Analysis of the Changing Functional Structure of Major Urban Centers of Ethiopia
}

\author{
Engida Esayas ${ }^{1}$ and Solomon Mulugeta ${ }^{2}$
}

\begin{abstract}
The study attempted to analyze the patterns of the changing functional structure of major urban centers of Ethiopia over the period of 2009 to 2012. An economic base, export employment multiplier and shift share analysis were used to identify the basic sectors, the export employment and expanding and declining industries in fifteen major urban centers. The location quotient results showed that there have been changes in economic bases, for twelve out of fifteen urban centers. The major sources of export employment were construction, distributive and social services for most of the towns considered. Export employment analysis has indicated that some towns of leading regions have relatively higher percentage of export employment compared to others. In general, the major drivers of the urban employment growth in many urban centers over the study period were found to be distributive, social and extractive sectors. However, the role of the transformative economic sectors, particularly the manufacturing sector is not as such encouraging for many towns. Against this back drop, the analysis surfaced local economic development issue such as how the towns included in this study could capitalize more on the transformative economic sectors through various incentive mechanisms.
\end{abstract}

Keywords: Urban Functions, Basic Employment, Employment Multiplier, Location Quotient, Shift Share Analysis

DOI: http://dx.doi.org/10.4314/ejbe.v4i2.2

\footnotetext{
${ }^{1} \mathrm{PhD}$ Candidate, Department of Geography \& Environmental Studies, College of Social Sciences, Addis Ababa University, Email: engesay2007@yahoo.com, Tel:+251911924152

${ }^{2}$ Associate Professor of Urban \& Regional Planning, Department of Geography \& Environmental Studies, College of Social Sciences, Addis Ababa University
} 


\section{Changes in Urban Functional Structure in Ethiopia}

\section{Background}

Urban centers exist, primarily, for the purpose of efficient performance of functions to support its population and surrounding rural and other urban areas (Carter, 1995; Pacione, 2009). The efficient performance of urban functions was made possible by labor specialization and centralized production in urban areas which in turn makes urban areas preferable to work and live. As such, urban areas are classified by virtue of the functions they perform as commercial towns, administrative headquarters, mining towns, manufacturing towns, centers of communication, storage, transfer and distribution, education and other social services (Nelson, 1955; Carter, 1995). According to many writers (Roberts, et al., 2006 \& Pacione, 2009), urban centers are viewed as the primary engines of economic growth, social wellbeing, centers of creativity, innovation and primary location of social transformation.

It is of particular importance to note that every town and city has an economic base. Hence, urban centers depend on economic activities for their sustained growth mainly by generating and injecting external income. However, all urban economic activities could not help bring income into the city. It is the nature and number of the basic activities they perform which generally determine economic growth of towns and cities. In this respect, some towns tend to specialize in one or two predominant functions while others are diversified, being multifunctional. Despite the fact that, towns and cities are expected to be functionally diversified mainly in their basic industries because their growth depends on the income earned from these sectors and the employment multiplier that could be created in the non-basic sectors of the economy as a result (Hustedde et al, 1993; Robert et al., 2006; Edwards, 2007). Due to the dynamic and unpredictable global and local circumstances, urban functions and their importance change over time. Hence, monitoring the regional/urban industrial change over time is the major responsibility of urban authorities.

It is inevitable and evident that the urban population and economy continue to grow in size and complexity and there is a need to understand the urban economy in Ethiopia. Therefore, understanding the recent progress of the urban economy including its relative strengths and weaknesses is necessary in order to formulate strategies to existing and/or new economic challenges and make 
informed decisions in managing urban economic growth. This understanding can come from a detailed analysis of the functional changes of the urban employment. To this end, the analysis could be done by using location quotients and shift share techniques which help measure the regional and/or urban economy.

Ethiopia's urban centers are characterized by spontaneous growth, a poorly developed economic base, a high level of unemployment and incidence of poverty (Ministry of Finance \& Economic Development (MoFED), 2007). The economic base of most urban centers, mainly of small and medium towns, is dominated by mainly public administration and distributive services (Solomon Mulugeta, 2008). But, theoretically, they are expected to be centers of transformative industries such as manufacturing, construction and others. The pre-1991 urban industrial history of Ethiopia has indicated that secondary economic as well as commercial and business activities were confined to the capital, Addis Ababa and some towns which were better located along the main transport routes. However, most large-sized urban centers have exhibited dramatic growth following the administrative decentralization and granting of autonomy after 1991. Thus, it appears from the recent trends of industrial employment that other regional towns are becoming alternative centers of investment.

The analysis of urban function is indispensable to regional planning fields (Carter, 1995), because overall urban activities are dynamic and cities and towns cannot exist without functions. Moreover, the functional change analysis could help policy makers, planners and urban governments better understand the dynamics of the economy of their urban centers which could, in turn, help in making better economic development plans and monitoring of economic growth of towns and cities and more specifically by industrial targeting. It is with these rationales this study is conducted for fifteen major urban centers of Ethiopia, by employing location quotient and shift share analysis techniques for the time span of 2009 to 2012 Gregorian calendar. This period is selected because employment data are available by major industry divisions for the towns included in the Central Statistical Agency (CSA) Urban Employment Unemployment Surveys (UEUS) that could help analyze using the techniques indicated above.

EJBE Vol. 4 No. 2/2014

Page 222 
Changes in Urban Functional Structure in Ethiopia

\section{Purpose of the Study}

The purpose of this paper was to identify the changes which have been taking place in the functional composition of the major urban centers of Ethiopia. In line with the objectives of the study, the study attempted to answer the following questions.

i. Which sectors and industries/services drive the major towns' economy in Ethiopia?

ii. What proportion of the labor force in the major towns of Ethiopia work in the export sector?

iii. How well are the different sectors of the major towns' economy performing relative to the national economy?

\section{Theoretical Frameworks}

\subsection{Measuring Regional/Urban Economic Performance}

It is a well recognized fact that the economy of a town/region is a sum total of its activities. Regional/urban economic development is mainly about the allocation or reallocation of resources to enhance the economic performance industries or services in the urban centers and regions (Robert et al., 2006). It is expected that planners and decision and policy makers should be able to understand the dynamics of the urban and regional economy of the area in consideration by measuring and evaluating the performance of the region in various sectors of the economy (Isard, 1960; Hustedde, et al., 1993). In light of this, Robert et al. (2006) have identified some of the necessary aspects of urban/regional economic development as follows: a) Measure the degree to which economic activity and employment in an area is related to serving local demand against serving demand external to the region (exports); b) Assess an area's overall performance relative to other regions; c) Identify the industry which perform better in the region and d) Assess a given industry's efficiency relative to other sector's performance.

To such end, there are various theories which help explain the urban and/or regional economic growth. Some of these include economic base theory, input output models and growth pole theory. In this study, however, focus is given to export/economic base theory because this study deals with the functional changes in the urban employment. Within the framework of the economic base 


\section{Changes in Urban Functional Structure in Ethiopia}

model, there are various tools that have been developed by regional scientists and practitioners to measure and analyze the performance of an area over time with respect to industrial employment. In the following section, the most common ones will be discussed.

\subsubsection{Economic Base Theory}

The economic base concept emerged in the 1940s and popularized in the 1960s with a need to predict the effect of new economic activity on a region. It is an easily understood technique of analysis of the regional economic development. It assumes that all urban functions can be classified as basic (export) and nonbasic (local marked oriented). The former is designated as 'city forming' and the later as 'city serving' mainly in urban geography (Carter, 1995). The one which drives the town's economy is the basic/export sector. Accordingly, the town's economy is strong and its future is promising if it develops those sectors that are not closely tied to local consumption (Isard, 1960; Roberts, et al., 2006); but rather in the export base. Thus, a diversified basic function helps expand the town's economy and reduces its vulnerability to single sector dependence (Edwards, 2007).

The economic base theory argues that the means of strengthening and growing the local economy are to develop and enhance the basic sector. The basic sector is, therefore, identified as the engine of the local economy that is why it is called the economic base of the local economy. It drives the town's growth by creating additional jobs in the non-basic or city serving sectors. This is so because basic sectors produce goods and services for export outside the local area or region. On the other hand, non-basic industries produce goods and services for consumption in the local area or region (Isard, 1960; Dinc, 2002). An areas export activity can be identified by the use of several analysis techniques. Two of the most well known economic base analysis techniques are the Location Quotient (LQ) and shift Share analysis (SSA) (Robert et al., 2006). As to Edwards (2007) LQ is a well known measure of the urban economy because it helps identify the basic and non-basic sectors of the economy.

EJBE Vol. 4 No. 2/2014

Page 224 


\subsubsection{Location Quotients (LQ)}

LQ is a simple but the standard technique used to identify the town's or region's economic base. It is a measure of an industry concentration in a town/region relative to the larger reference area, which is generally the nation. It compares an industry's share of regional employment with its share of national employment (Isard, 1960; Carter, 1995; Dinc, 2002; Robert et al., 2006).

Particularly, based on Robert et al. (2006:107-108), the LQ for various sectors of the economy could be computed using the formula given below as follows:

$\mathbf{L Q}=\left(\mathbf{e}_{\mathbf{i}} / \mathbf{e}\right) /\left(\mathbf{E}_{\mathbf{i}} / \mathbf{E}\right)$, where

$\mathbf{L Q}=$ Location Quotient

$\mathbf{e}_{\mathbf{i}}=$ Local employment in the $\mathrm{i}^{\text {th }}$ industry

$\mathbf{e}=$ Total Local Employment

$\mathbf{E}_{\mathbf{i}}=$ National Employment in the $i^{\text {th }}$ industry

$\mathbf{E}=$ Total National Employment

Based on the computation, if $L Q=1$, then the industry's share of the regional employment is the same the industry's share nationally implying that the region is self-sufficient. When LQ>1, it implies that the industry produces more goods and services than are consumed regionally. Hence, the industry is exporting the goods and services and bringing money into the regional area, which promotes the regional economic growth. On the other hand, when $\mathrm{LQ}<1$, it implies that the industry's share of the regional employment is smaller than its share of national employment and hence it imports the deficiency from outside. Generally LQ measures the industry concentration that can be used to interpret whether an area is self-sufficient, is an importer or an exporter. The greater the LQ, the more significant the sector is to the local economy. Industries providing basic sector employment are considered more attractive from an economic development perspective, since they bring income from outside the city and help to create supporting employment in non-basic sectors (Isard, 1960; Hustedde et al, 1993; Robert et al., 2006; Edwards, 2007). Despite the ease of applicability of LQ methods, it has limitations. For instance, the more the data is aggregated, the more the details will be hidden and LQ can vary with the levels of industry aggregation. Moreover, unless it is used together with other analytical methods, it does not help explain the change 
in the economy (Isard, 1960, Dinc, 2002). Despite its weaknesses, it has been widely applied in the regional/urban analysis across the world. For instance, Huang (1977) used in the study of economic base, industrial specialization and diversification of Taiwan. The other study is of Kaizhong (1998) which focused on basic features and trends of the economic base of Beijing, China. Moreover, in a recent study, Quintero (2007) has applied LQ in his analysis of Hays County, Texas, United States of America.

\subsubsection{Export Base Multiplier}

An economic or export base multiplier is the fundamental concept in economic base theory particularly in the explanation of urban/regional economic growth (Isard, 1960; Mullingan, 2008; Pacione, 2009). The multiplier effects are one of the basic mechanisms of the local and regional development and occur when the basic sector economic activity affects the local activity by creating additional job in the local sectors. According to Edwards (2007), the economic base multiplier measures the growth in non-basic economy as a result of growth in the basic sector. It is, therefore, a useful predictive tool since it deals with the effect of basic sector growth on non-basic sectors. As such, it measures the effect of each new job created in basic industry on total employment in the economy (Hustedde et al., 1993; Domanski \& Gwosdz, 2010). As it has been discussed, the export base multiplier could provide insights as to how many non-basic sector jobs have been created by one basic job and ultimately how changes in employment in the basic sector could influence the overall economy of the town. However, one should bear in mind while using export base multiplier that it could be affected by the size of the town's population and employment, geographic isolation and specialization (Roberts et al., 2006; Edwards, 2007).

According to Domanski \& Gwosdz (2010), the two methods of calculating the multiplier effects are the incremental and aggregate methods. In the aggregate methods, the multipliers are calculated not in agreement with the theoretical underpinnings of the economic base model and hence it appears the most difficult one. Alternatively, the best and proper way to measure multiplier is to estimate incremental change in a particular industry employment and then assess changes in overall economic activity level in a given geographic area. 
The economic base multiplier is calculated, in this study, as a ratio of the total employment of a town to basic sector employment in that city (Hustedde, et al., 1993).

\subsubsection{Shift Share Analysis (SSA)}

SSA is a descriptive technique for analyzing regional or urban economic change, i.e. growth or decline over time (Dinc, 2002; Robert, et al., 2006). It provides useful information about the characteristics of growth and competitiveness of local industries in a locality compared to a larger reference area. The technique is used for decomposing changes in employment in towns or regions identifying competitive industries in the local economy compared to the national industries. In particular, it also helps determine whether a particular local economy has experienced a faster or slower growth rate in employment than the larger economy (Chan, 2011).

Based on the analysis of SSA, it is possible to identify industries which gained or lost additional employment in a given period. SSA allows analyzing changes in the number of jobs in terms of structural change, not just a general change in total employment in a locality. Hence, SSA is extensively used by geographers, regional scientists, economists and planners in regional analysis because it emphasizes not only on the role of regional change for region-specific industry but also the regional shift or competitive component as a measure of the relative performance of the region for specific industries (Dinc, 2002; Robert et al., 2006). Because of this practical matter, it is particular importance assessing the impacts of industrial restructuring and providing guidance for industrial targeting (Dinc, 2002).

The urban economies and the rate of employment in industries through time may change for a number of reasons. As is discussed earlier, the LQ does not help identify why the change has taken place. But, somehow, the SSA identifies the factors that contributed to the growth and change in the town's economy by separating national, industrial and town-specific or local trends from each other. In this regard, the traditional SSA decomposes employment change in a region over a given period of time, three contributing factors (Roberts, et al., 2006; Edwards, 2007): 
i. National Growth Effect: This represents the share of local employment growth that can be attributed to the growth of the national economy. It is based on the assumption that if the larger economy is experiencing employment growth, it is reasonable to expect that this growth will positively influence employment growth in a particular locality (Dinc, 2002).

ii. Industry mix effect: It represents the effects that specific industry trends at the national level have had the change in employment in the locality. It captures nationally some industries grow faster or slower than others and these differences are reflected in the local industry. Based on the computation, a positive industry mix implies that the employment in the locality grew above the overall national averages and a negative industry mix indicates the opposite (Robert, et al., 2006).

iii. Competitive Share Effect: It is primarily based on the assumption that for the same industry groups, sometimes the locality may not follow the national trends with the same magnitude. This is mainly because the region might have the competitive advantage of a natural resource base, labor resource and so forth. Based on the computation of positive share component suggests that the locality increased its share employment in that industry and a negative competitive component share means the opposite.

Based on Robert et al. (2006) and Quintero (2007), the formula for the three shift share components i.e. National Growth Effect, Industry Mix Effect and Competitive Share Effect, have been given as follows:

$$
\begin{aligned}
& \mathbf{N G}=\mathbf{R e}_{\mathbf{i}}\left(\mathbf{N E}_{\mathbf{j}} / \mathbf{N E}_{\mathbf{i}}-\mathbf{1}\right) \\
& I M=\mathbf{R e}_{\mathbf{i}}\left(\mathbf{N e}_{\mathbf{j}} / \mathbf{N e}_{\mathbf{i}}\right)-\left(\mathbf{N E}_{\mathbf{j}} / \mathbf{N E}_{\mathbf{i}}\right) \\
& \mathbf{C S}=\mathbf{R e}_{\mathbf{i}}\left(\mathbf{R e}_{\mathbf{j}} / \mathbf{R e}_{\mathrm{i}}\right)-\left(\mathrm{Ne}_{\mathrm{j}} / \mathrm{Ne}_{\mathrm{i}}\right) \text {, Where } \\
& \text { NG=National Growth Effect } \\
& \text { IM =Industry Mix Effect } \\
& \mathbf{C S}=\text { Competitive Share Effect }
\end{aligned}
$$

$\mathbf{R e}_{\mathbf{i}}$ is regional employment in a given industry at the beginning of the period

$\mathbf{R e}_{\mathbf{j}}$ is regional employment in a given industry at the end of the period

$\mathbf{N e}_{\mathbf{i}}$ is national employment in a given industry at the beginning of the period 
$\mathbf{N e}_{\mathbf{j}}$ is national employment in a given industry at the end of the period

$\mathbf{N E}_{\mathbf{i}}$ is total national employment at the beginning of the period

$\mathbf{N E}_{\mathbf{j}}$ is total national employment at the end of the period

Total Employment Change $($ TEC $)=\mathbf{N G}+\mathbf{I M}+\mathbf{C S}$

Thus, the aggregate of the three components indicate the structural change in the town's economy over the study period. It shows the difference between the end year employment structure and base year employment structure. The above method is the most relevant technique for regional or urban economic analysis because it makes a significant contribution to the understanding and selection of key leading industries in the town. Moreover, by interpreting the results of SSA, it is possible to explore the advantage of the local area as well as to identify growth; decline, or potential growth industries that are worthy of further investigation (Dinc, 2002; Robert et al., 2006).

Despite the above discussions on its applications and advantages, it is undeniable fact that it does not fully account for all factors that may contribute or explain the change in the regional/urban employment/economies. Thus, for full understanding of the economic change it is strongly recommended that one has to use a mix of analytical methods together with the SSA (Dinc, 2002). In spite of its limitations, since its introduction in the 1960s, SSA has been adopted and applied to a variety of regional/urban issues. For instance, regional growth analysis in Canadian manufacturing industry (Paraskevopoulos, 1974), analysis of Hays County, Texas, USA (Quintero, 2007) and the most recent study of Ping \& Hui (2012) on the quantitative economic analysis of the industrial structure of coastal city of Shandong province. Therefore, it appears worthy to use this analytical tool in studies of this kind.

\section{Methodology}

\subsection{Study Design}

This study has tried to explore the functional change in urban centers of Ethiopia between 2009 and 2012 using LQ and SSA methods. The LQ is used to identify the unique structural components of the economy of urban centers, i.e. identifying the basic and non-basic sectors of the urban economy. However, identifying merely these sectors misses important trends in the 
economy. Hence, to identify the dynamic components of the urban centers functional change, a shift share analysis is used. As discussed earlier, this technique decomposes change in the urban functions into three components: NG, IM and CS components. One of the weaknesses of the LQ is that it offers only a snapshot view of the town's employment changes. The SSA, however, shows a broader picture of functional change in the town's employment over time. It points industries that may be declining or growing either nationally, locally or both at both spatial levels (Quintero, 2007).

\subsection{Sources of Data}

The major urban centers included the Statistical Report on UEUS of CSA, covering employed population of urban areas aged ten years and above by major industrial divisions, are central to the design of this study. The study towns include 15 urban centers: Mekelle, Asayita, Gondar, Dessie, Bahir Dar, Bishoftu, Adama, Jimma, Jigjiga, Assosa, Hawassa, Gambella, Harar, Addis Ababa and Dire Dawa. All the raw data taken from the UEUS for the years 2009 and 2012. However, the previous surveys do not have employment data by industrial divisions for the towns considered.

\subsection{Analytical Procedures \\ i. Location Quotients}

As indicated earlier, the formula for computing LQ is given as: $\mathbf{L Q}=\left(\mathbf{e}_{\mathbf{i}} / \mathbf{e}\right) /$ $\left(\mathbf{E}_{\mathbf{i}} / \mathbf{E}\right)$. For example, LQ for Mekele of manufacturing sector in 2012, given total employment in Mekele town $(21,846)$, major towns' total employment in manufacturing $(284,019)$, total employment of the town $(121,116)$ and that of major towns' total $(2,212,903)$, is calculated as follows:

$\mathbf{L Q}=\left(\mathbf{e}_{\mathrm{i}} / \mathbf{e}\right) \quad / \quad\left(\mathbf{E}_{\mathbf{i}} / \mathbf{E}\right)=(21,846 / 284,019) \div(121,116 / 2,212,903)=$ $0.07692 / 0.05473=\mathbf{1 . 4 1}$.

Based on the calculation of LQ, the basic and non-basic sectors of Mekele town are identified and given in Table 3.1:

EJBE Vol. 4 No. 2/2014 
Changes in Urban Functional Structure in Ethiopia

Table 3.1. Basic and Non basic industrial employment for Mekele Town, 2009\&2012

\begin{tabular}{|c|c|c|c|c|c|}
\hline Sector & LQ & Comment & Sector & LQ & Comment \\
\hline Agriculture, hunting, & & & Transport, storage \& & & \\
\hline forestry \& fishing & 0.63 & Local & Communication & 0.85 & Local \\
\hline Mining \& Quarrying & 2.74 & Basic & Financial intermediation & 0.57 & Local \\
\hline Manufacturing & 1.41 & Basic & Real Estate \&Renting & 0.49 & Local \\
\hline Electricity, gas \&water & & & Public administration \& Defense & & \\
\hline supply & 1.07 & Basic & Education & 0.98 & Local \\
\hline Construction & 1.16 & Basic & Health \& Social Work & 0.80 & Local \\
\hline Wholesale \&Retail & 0.86 & Local & Other social \&Community & 1.10 & Basic \\
\hline Hotel \& Restaurants & 1.16 & Basic & activities & 0.08 & Local \\
\hline
\end{tabular}

Source: Based on computed LQ from CSA $2009 \& 2012$

\section{ii. Calculate basic employment and export employment multiplier}

Basic employment estimates the number of sector's employment that contribute to export base. Therefore, a town's basic employment is a ratio of total local industry employment divided by the total national industry employment subtracted from the ratio of total local employment divided by total national employment multiplied by the total national industry employment.

\section{Basic Employment $(\mathbf{B E})=\left[\left(\mathbf{e} / \mathbf{E}_{\mathbf{i}}\right) /(\mathbf{e} / \mathbf{E})^{*} \mathbf{E}_{\mathbf{i}}\right]$}

Thus, for the purpose of calculating the estimated export employment contribution made by the manufacturing sector in the same year for the same data as used in LQ above is calculated as follows:

$\mathbf{B E}=[(21,846 / 284,019) /(121,116 / 2,212,903) * 284,019]=\mathbf{6}, \mathbf{3 0 2}$

Accordingly, from the total manufacturing employment in Mekele, in the year 2012, 6302 employees are directly contributing to the export base.

The impact of basic employment on local employment is known as export base multiplier. The export base multiplier is calculated as a ratio of total local employment divided by total basic employment. The resulting figure reflects the total number of jobs created in return for each new basic job. Given the 
total local employment, 110,455 and total export employment, 10,661, then, the export employment multiplier is calculated as 10.36 , which means one export job created, on the average, about 10.36 jobs in the non-basic sector in the year 2012.

In this study export base multiplier is measured for each town; not specific sectors, after identifying the basic-non-basic employment for each based on LQ. The multiplier is calculated only if the LQ > 1, and logic is that export employment does have a multiplier effect in that it creates additional jobs in local employment (Robert et al., 2006).

\section{iii. Shift Share Analysis}

The first phase of SSA is the preparation of base year and end year employment data set. Accordingly, the base year employment data set refers to the year 2009 for specific towns and the end year employment is referring to 2012 for both regions and specific urban centers.

The next step is calculating the shift share components i.e. NG, IM and CS effects. This was done using the formula by Robert, et al. (2006:114-115).

Again, for Mekele town using the manufacturing employment, the three shift share components, are calculated as follows:

Table 3.2: Parameters for Computing SSA of Employment for Towns 2009-2012

\begin{tabular}{|c|c|c|}
\hline Parameters & Symbol & Value \\
\hline Total employment in manufacturing in Mekele in 2009 & $\mathbf{R e}_{\mathbf{i}}$ & 4,329 \\
\hline Total employment in manufacturing in Mekele in 2012 & $\mathbf{R e}_{\mathbf{j}}$ & \\
\hline $\begin{array}{l}\text { Major Towns' Total employment in manufacturing in } \\
2009\end{array}$ & $\mathbf{N e}_{\mathbf{i}}$ & 21,846 \\
\hline $\begin{array}{l}\text { Major Towns' Total employment in manufacturing in } \\
2012\end{array}$ & $\mathrm{Ne}_{\mathbf{j}}$ & $\begin{array}{l}238,484 \\
284,019\end{array}$ \\
\hline Major Towns' Total Employment in 2009 & $\mathbf{N E}_{\mathbf{i}}$ & \\
\hline Major Towns' Total Employment in 2012 & $\mathbf{N E}_{\mathbf{j}}$ & $\begin{array}{l}1,729,752 \\
2,212,903\end{array}$ \\
\hline
\end{tabular}

EJBE Vol. 4 No. 2/2014 


$$
\begin{aligned}
& \mathbf{N G}=\mathbf{R e}_{\mathbf{i}} *\left(\mathbf{N E}_{\mathbf{j}} / \mathbf{N E} \mathbf{i}_{\mathbf{i}} \mathbf{- 1}\right)=4,329[(2,212,903 / 1,729,752)-1]=\mathbf{1 , 2 0 9} \\
& \mathbf{I M}=\mathbf{R e}_{\mathbf{i}} *\left(\mathbf{N e}_{\mathbf{j}} / \mathbf{N e}_{\mathbf{i}}\right)-\left(\mathbf{N E} \mathbf{E}_{\mathbf{j}} / \mathbf{N E}_{\mathbf{i}}\right)=[4,329(284,019 / 238,484)- \\
& (2,212,903 / 1,729,752)]=\mathbf{- 3 8 3} \\
& \mathbf{C S}=\mathbf{R e}_{\mathbf{i}} *\left(\mathbf{R e}_{\mathbf{j}} / \mathbf{R e}_{\mathbf{i}}\right)-\left(\mathbf{N e}_{\mathbf{j}} / \mathbf{N e} \mathbf{N e}_{\mathbf{i}}\right)=[4,329(21,846 / 4,329)-(2284,019 / 238,484)] \\
& =\mathbf{1 6 , 6 9 0} \\
& \text { Total Employment Change = NG+IM+CS = 1209-383+16690 =17,516 }
\end{aligned}
$$

In a similar fashion, when calculated, the major towns' total shift in manufacturing employment is $40,432(100 \%)$. Taking major towns' total, the above values can be changed into percentages as NG $(2.99 \%)$, IM (-0.95\%), CS (41.28 \%) and TEC (43.32\%) respectively. This will be discussed in detail in the analysis and discussion section. To give a highlight example of analysis, from this total shift, about $43.32 \%$ occurred in Mekele town. There has been a positive NG effect in Mekele (2.99\%). This implies that NG in the manufacturing sector has positively influenced the manufacturing employment in Mekele. The most interesting aspect is that Mekele is the most competitive town for the manufacturing employment than any other town of Ethiopia, which is $41.28 \%$. Hence, it is expected that, in the future, Mekele town will capture more manufacturing employment.

\section{Functional Changes in the Major Urban center of Ethiopia 5.1 Functional change in the leading regional capitals \& urban regions of Ethiopia}

By leading regional capitals it refers to the capitals of the leading regions in Ethiopia namely Mekele, Bahir Dar and Hawassa. The urban regions are those having the lion's share of their population being urban. These included Harar, Dire Dawa and the capital Addis Ababa. The functions of these towns have been identified and presented in Table 4.1, in order of importance based on their respective LQs. The first rank implies the dominant or basic sector for which the LQ is highest and followed by the second and the third ranked basic functions. 
Changes in Urban Functional Structure in Ethiopia

Table 4.1: Economic bases of leading regional capitals and urban regions (2009 \& 2012)

\begin{tabular}{|c|c|c|c|c|}
\hline \multirow[t]{2}{*}{ Town } & \multirow[t]{2}{*}{ Year } & \multicolumn{3}{|c|}{ Basic Sectors in order of importance } \\
\hline & & $\mathbf{1}^{\mathrm{st}}$ & $2^{\text {nd }}$ & $3^{\text {rd }}$ \\
\hline \multirow[b]{2}{*}{$\begin{array}{l}\frac{0}{\overline{0}} \\
\frac{\mathscr{v}}{2}\end{array}$} & 2009 & $\begin{array}{l}\text { Transport, storage \& } \\
\text { communications }\end{array}$ & $\begin{array}{l}\text { Public admin. \& } \\
\text { Defense }\end{array}$ & construction \\
\hline & 2012 & Mining \&Quarrying & Manufacturing & $\begin{array}{l}\text { Construction } \\
\text { Hotels \& } \\
\text { restaurants }\end{array}$ \\
\hline \multirow[b]{2}{*}{ 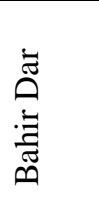 } & 2009 & $\begin{array}{l}\text { Public admin. \& } \\
\text { Defense }\end{array}$ & $\begin{array}{l}\text { Real Estate, renting \& } \\
\text { business activities }\end{array}$ & $\begin{array}{l}\text { Hotels \& } \\
\text { Restaurants }\end{array}$ \\
\hline & 2012 & $\begin{array}{l}\text { Other community, } \\
\text { social \& personal } \\
\text { services }\end{array}$ & Mining \& quarrying & $\begin{array}{l}\text { Hotels \& } \\
\text { Restaurants }\end{array}$ \\
\hline \multirow[b]{2}{*}{ 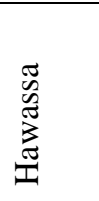 } & 2009 & $\begin{array}{l}\text { Public admin. \& } \\
\text { Defense }\end{array}$ & Education & $\begin{array}{l}\text { Health \& social } \\
\text { work }\end{array}$ \\
\hline & 2012 & $\begin{array}{l}\text { Other community, } \\
\text { social \& personal } \\
\text { services }\end{array}$ & $\begin{array}{l}\text { Electricity, gas \&water } \\
\text { supply }\end{array}$ & Education \\
\hline \multirow[b]{2}{*}{ 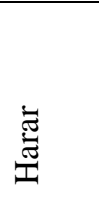 } & 2009 & $\begin{array}{l}\text { Health and social } \\
\text { work }\end{array}$ & Mining and quarrying & Education \\
\hline & 2012 & Mining and quarrying & $\begin{array}{l}\text { Other community, } \\
\text { social \& personal } \\
\text { services activities }\end{array}$ & $\begin{array}{l}\text { Public admin. \& } \\
\text { Defense }\end{array}$ \\
\hline \multirow{2}{*}{ 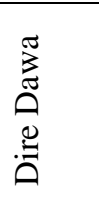 } & 2009 & Construction & Health \& social work & $\begin{array}{l}\text { Real Estate, } \\
\text { renting \& business } \\
\text { activities }\end{array}$ \\
\hline & 2012 & Mining \& quarrying & $\begin{array}{l}\text { Wholesale \& Retail } \\
\text { Trade }\end{array}$ & $\begin{array}{l}\text { Electricity, gas } \\
\text { \&water supply }\end{array}$ \\
\hline \multirow[b]{2}{*}{$\frac{n}{7} \frac{\pi}{0}$} & 2009 & Mining \& quarrying & $\begin{array}{l}\text { Financial } \\
\text { intermediation }\end{array}$ & $\begin{array}{l}\text { Electricity, gas } \\
\text { \&water supply }\end{array}$ \\
\hline & 2012 & $\begin{array}{l}\text { Other community, } \\
\text { social \& personal } \\
\text { services }\end{array}$ & $\begin{array}{l}\text { Financial } \\
\text { intermediation }\end{array}$ & $\begin{array}{l}\text { Wholesale \& } \\
\text { Retail Trade }\end{array}$ \\
\hline
\end{tabular}

All towns, in this category, have reflected changes in their basic functions in the study period; though the change is not the same for all of them. In some of them, substantial change occurred in their functions. For example, transport, storage and communications, public administration and defense, and construction were the top most four basic sectors of Mekele town in 2009. However, this has been changed, to a considerable degree, in the year 2012, whereas, mining, manufacturing, construction, hotels and restaurants became 
the top basic economic activities of the town indicating that the transformative sectors are taking the lead in the town noticeably.

In Bahir Dar, the capital of Amhara National Regional State (ANRS) and the political and administrative center, public administration and defense dominated followed by real estate, renting and business activities and hotels and restaurants in the year 2009. But, in 2012, other community, social and personal service activities, mining, hotels and restaurants and construction were the backbones of the economy indicating a complete change in its basic industries between 2009 and 2012.

In Hawassa, the capital of the Southern Nations, Nationalities and Peoples' Region (SNNPR) and the political and administrative headquarter, public administration and defense, education, health and social work, construction and hotels and restaurants were the top five economic functions in 2009. However, this has been changed in 2012 with some reordering and addition of new basic functions. Accordingly, other community, social and personal service activities, followed by electricity, gas, and water supply, education, health and social work, public administration and defense and agriculture as the dominant basic sectors of the town pinpointing the dynamics economic and employment change in the regional cities.

Harar, which is the oldest medieval town in eastern Ethiopia, has undergone slight changes in its basic functions over the study period. Health and social work, mining, education, public administration and defense and wholesale and retail trade were the dominant functions in 2009. In 2012, however, mining, other community, social and personal service activities, public administration and defense, wholesale and retail trade and electricity, gas and water supply became the basic functions of the town. The growth of the transformative sectors is unimpressive in the town as its growth primarily dependent upon extractive, distributive and social services.

Dire Dawa, the second largest town, next to the Capital Addis Ababa, has revealed changes in functional structures between the years considered to a certain degree. Construction, health and social services, real estate, renting and business service activities, financial intermediation and hotels and restaurant were the five leading functions of the town in 2009. When it comes its dominant functions in 2012, surprisingly enough, mining, wholesale and retail trade, electricity, gas and water supply, agriculture and health and social work 
were the major economic bases of the town. Though the city is thought to be the center of the manufacturing activities; it appears that the employment in secondary sectors is not encouraging.

The national administrative and political headquarter, Addis Ababa, though, has been the commercial, business and manufacturing hub for the past history of urbanization in Ethiopia. Like other towns, it has also gone through changes in its major economic functions in the study period. Relatively speaking, it is more multifunctional compared with other towns considered in this study owing to its primacy effect. However, other towns, too, are becoming multifunctional; though not equally comparable to that of Addis Ababa. The multifunctionality, of Addis Ababa, is exhibited in the fact that in 2009, mining, financial intermediation, electricity, gas and water supply were the three top functions of the capital. Whereas, in 2012, other community, social and personal service activities, financial intermediation, real estate, renting and business service activities, transport storage and communications and lastly manufacturing appeared to have been dominant economic sectors in decreasing order of importance respectively.

\subsubsection{Functional Changes in some secondary towns of Ethiopia}

Provincial capitals are towns which are not serving as regional headquarters but they may be zonal capitals. These towns included Gondar, Dessie, Adama, Jimma and Shashemene. Shashemene town did not industrial employment data in the UEUS before 2010. 
Changes in Urban Functional Structure in Ethiopia

Table 4.2: Economic bases of some secondary towns in Ethiopia (2009 \& 1012)

\begin{tabular}{|c|c|c|c|c|}
\hline \multirow[t]{2}{*}{ Town } & \multirow[t]{2}{*}{ Year } & \multicolumn{3}{|c|}{ Basic Sectors in order of importance } \\
\hline & & $1^{\text {st }}$ & $2^{\text {nd }}$ & $3^{\text {rd }}$ \\
\hline \multirow[t]{2}{*}{ Gondar } & 2009 & Agriculture & $\begin{array}{l}\text { Hotels \& } \\
\text { Restaurants }\end{array}$ & NA (Not Available) \\
\hline & 2012 & $\begin{array}{l}\text { Other community, } \\
\text { social \& personal } \\
\text { services }\end{array}$ & Agriculture & $\begin{array}{l}\text { Electricity, gas } \\
\text { \&water supply }\end{array}$ \\
\hline \multirow[t]{2}{*}{ Dessie } & 2009 & Education & $\begin{array}{l}\text { Mining \& } \\
\text { quarrying }\end{array}$ & $\begin{array}{l}\text { Other community, } \\
\text { social \& personal } \\
\text { services activities }\end{array}$ \\
\hline & 2012 & $\begin{array}{l}\text { Public admin. \& } \\
\text { Defense }\end{array}$ & $\begin{array}{l}\text { Health and } \\
\text { social work }\end{array}$ & $\begin{array}{l}\text { Wholesale \& Retail } \\
\text { Trade }\end{array}$ \\
\hline \multirow[t]{2}{*}{ Adama } & 2009 & Hotels \& Restaurants & Construction & $\begin{array}{l}\text { Wholesale \& Retail } \\
\text { Trade }\end{array}$ \\
\hline & 2012 & $\begin{array}{l}\text { Other community, } \\
\text { social \& personal } \\
\text { services }\end{array}$ & $\begin{array}{l}\text { Transport, } \\
\text { storage \& } \\
\text { communication } \\
\text { s }\end{array}$ & Education \\
\hline \multirow[t]{2}{*}{ Jimma } & 2009 & Education & Construction & Health \& Social Work \\
\hline & 2012 & Education & Construction & Health \& Social Work \\
\hline \multirow{2}{*}{$\begin{array}{l}\text { Shasheme } \\
\text { ne }\end{array}$} & 2009 & NA & NA & NA \\
\hline & 2012 & Agriculture & $\begin{array}{l}\text { Wholesale \& } \\
\text { Retail Trade }\end{array}$ & Hotel \& Restaurant \\
\hline
\end{tabular}

Source: Based on computation from UEUS $(2009,2012)$

As could be seen from Table 4.2, in 2009, what drives the export employment growth of Gondar were extractive and tourism, these were, agriculture, hunting, fishing and forestry and hotels and restaurants. However, in 2012, it had three basic functions which included other community, social and personal service activities, agriculture, electricity, gas and water supply respectively. For Dessie town, education, mining, other community, social and personal service activities, construction and financial intermediation were the major economic bases in 2009. While, in 2012, public administration and defense, health and social work, wholesale and retail trade, education and construction were the dominant sources of the export employment.

Adama, which is supposed to be the centre of transport, storage and communications as it is located at break-of-bulk point, has been showing a different story. For instance, in 2009, hotels and restaurants, construction, 
wholesale and retail trade, transport, storage and communications and manufacturing were dominating. Whereas other community, social and personal service activities, transport, storage and communications, manufacturing, wholesale and retail trade and hotel and restaurant were found to be basic activities in 2012. Yet the role of transport, storage and communications cannot be overlooked in Adama town. Though it is not the first ranked functions, as it was the case before 2008 as pointed out by Solomon Mulugeta (2008), it is among the basic sectors of the town, suggesting that as the town expanded, other basic activities are taking the lead. Unlike other urban centers of its size, Jimma has never made a change completely in functional structures over the study period. Thus, education, construction and health and social work remained to be dominant sectors of the town's economy in the period of 2009 to 2012. Shashemene, like Adama, another town located at break-of-bulk point i.e. located along Addis AbabaArba Minch and Addis Ababa-Hawassa-Moyale road, is the center of commerce as agriculture, wholesale and retail trade, hotels and restaurants, transport and communications are the four basic economic sectors of the town mainly in 2012.

\subsubsection{Functional change in towns of Emerging Regions of Ethiopia}

Towns of emerging regions include Assosa, Asayita, Jigjiga and Gambella. These regions have special affirmative action entitlements in development endeavors and are supported by the FDRE government under the special framework. Except Jigjiga, the remaining have a very low total population but three of them, with the exception of Asayita, are regional capitals being the political and administrative seats of Benishangul Gumuz, Somali and Gambella regions respectively. At present, Semera is serving as the headquarter of the Afar National regional State.

Like Jimma in the previous discussion, in Asayita also, there has never been changed in the first three dominant functions over the study period. Its export employment growth depends on agriculture, public administration and defense and hotels and restaurants. In Jigjiga, other community, social and personal service activities, health and social work, public administration and defense, transport, storage and communications and wholesale and retail trade were the 


\section{Changes in Urban Functional Structure in Ethiopia}

five major basic functions in 2009. There have been some changes in the order of basic functions as other community, social and personal service activities, public administration and defense, wholesale and retail trade, electricity, gas and water supply and health and social works have become the dominant functions of the town in 2012.

In Assosa, financial intermediation, agriculture, public administration and defense, education and health and social services were basic functions in 2009; whereas in 2012; agriculture, public administration and defense, hotels and restaurants, real estate, renting and business services and health and social work become basic activities. Change in the functional structure of Gambella is minimal. The first, the third and the fifth dominant functions remained the same as public administration and defense and agriculture, health and social work respectively. The change has only been observed in the second and fourth functions of the town. Mining has been replaced by hotels and restaurants and construction by education in 2012 respectively.

Table 4.3: Economic bases of Emerging Regional capitals (2009 \&2012)

\begin{tabular}{|c|c|c|c|c|}
\hline \multirow[t]{2}{*}{ Town } & \multirow[t]{2}{*}{ Year } & \multicolumn{3}{|c|}{ Basic sectors in order of importance to the town } \\
\hline & & $1^{\text {st }}$ & $2^{\text {nd }}$ & $3^{\text {rd }}$ \\
\hline \multirow[t]{4}{*}{ Asayita } & 2009 & Agriculture & Public admin. \& & Hotels \& \\
\hline & & & Defense & Restaurants \\
\hline & 2012 & Agriculture & Public admin. \& & Hotels \& \\
\hline & & & Defense & Restaurants \\
\hline \multirow[t]{4}{*}{ Jijiga } & 2009 & Other community, & Health \& Social Work & Public \\
\hline & & $\begin{array}{l}\text { social \& personal } \\
\text { services }\end{array}$ & & $\begin{array}{l}\text { administration \& } \\
\text { Defense }\end{array}$ \\
\hline & 2012 & Other community, & Public admin. \& & Wholesale \& Retail \\
\hline & & $\begin{array}{l}\text { social \& personal } \\
\text { services }\end{array}$ & Defense & Trade \\
\hline \multirow[t]{4}{*}{ Assosa } & 2009 & Financial & Agriculture & Public admin. \& \\
\hline & & Intermediation & & Defense \\
\hline & 2012 & Agriculture & Public admin. \& & Hotels \& \\
\hline & & & Defense & Restaurant \\
\hline \multirow{3}{*}{$\begin{array}{l}\text { Gambe } \\
\text { lla }\end{array}$} & 2009 & Public admin. \& & Mining \& quarrying & Agriculture \\
\hline & & Defense & & \\
\hline & 2012 & $\begin{array}{l}\text { Public admin. \& } \\
\text { Defense }\end{array}$ & Hotels and Restaurant & Agriculture \\
\hline
\end{tabular}

Source: Based on computation from UEUS (2009, 2012)

EJBE Vol. 4 No. 2/2014

Page 239 


\section{Changes in Urban Functional Structure in Ethiopia}

It appears from the changes in the functions of the towns of emerging regions is that the lesser the urban population, the less likely the major sectors take the lead and the less probable the economy to be diversified. It has been observed that economic activities like agriculture, public administration, defense and other community, social and personal service activities appear to have been the dominant activities of these towns, with the exception of Assosa which had financial intermediation as the basic activity only in 2009.

\subsection{Export Employment and Export Employment Multiplier}

As discussed earlier, the export base employment is a ratio of total employment divided by basic employment. It is very important analytical expression for it indicates the effect of local export employment over total local employment. In addition, export base multiplier helps to estimate local basic sector employment and allows analysts to project employment creation given an increase in basic sector employment. Therefore, the resulting figure of the export base multiplier reflects the total number of jobs created in return for each new export employment position.

Based on UEUS of CSA $(2009,2012)$ and the resulting computation of location quotients for various towns in respective sectors, export employment and local employment have been identified. Total local employment, total export employment and export employment in percent are presented in Table 4.4 . 
Changes in Urban Functional Structure in Ethiopia

\begin{tabular}{|c|c|c|c|c|c|c|}
\hline $\begin{array}{l}\text { Major } \\
\text { Towns }\end{array}$ & $\begin{array}{c}\text { Total Local } \\
\text { Employme } \\
\text { nt } \\
(2009)\end{array}$ & $\begin{array}{c}\text { Total } \\
\text { Export } \\
\text { Employme } \\
n t \\
(2009)\end{array}$ & $\begin{array}{c}\text { Percentage } \\
\text { of export } \\
\text { employme } \\
\text { nt }\end{array}$ & $\begin{array}{c}\text { Total Local } \\
\text { Employme } \\
\text { nt } \\
(2012)\end{array}$ & $\begin{array}{c}\text { Total } \\
\text { Export } \\
\text { Employme } \\
\text { nt } \\
(2012)\end{array}$ & $\begin{array}{c}\text { Percentage } \\
\text { of export } \\
\text { employme } \\
\text { nt }\end{array}$ \\
\hline Mekelle & 30,481 & 5,244 & 14.68 & 110,455 & 10,661 & 8.8 \\
\hline Asayita & 5,902 & 1,085 & 15.52 & 6,165 & 2,204 & 26.34 \\
\hline Gondar & 51,728 & 24,582 & 32.21 & 70,743 & 27,125 & 27.72 \\
\hline $\begin{array}{l}\text { Dessie } \\
\text { Bahir }\end{array}$ & 38,445 & 4,999 & 11.51 & 43,785 & 3,758 & 7.9 \\
\hline Dar & 65,913 & 10,664 & 13.93 & 81,672 & 12,109 & 12.91 \\
\hline Bishoftu & 30,965 & 8,960 & 22.44 & 32,811 & 8,473 & 20.52 \\
\hline Adama & 81,751 & 12,881 & 13.61 & 79,569 & 13,377 & 14.39 \\
\hline Jimma & 45,549 & 2,730 & 5.66 & 50,509 & 8,556 & 14.49 \\
\hline Jigjiga & 26,462 & 5,841 & 18.08 & 32,974 & 7,968 & 19.46 \\
\hline Assosa & 8,161 & 3,063 & 27.29 & 15,116 & 2,815 & 15.7 \\
\hline $\begin{array}{l}\text { Hawassa } \\
\text { Gambell }\end{array}$ & 60,338 & 6,424 & 9.62 & 114,449 & 12,622 & 9.93 \\
\hline $\mathrm{a}$ & 8,799 & 3,738 & 29.82 & 11,973 & 5,523 & 31.57 \\
\hline Harar & 34,779 & 7,585 & 17.91 & 40,135 & 9,834 & 19.68 \\
\hline AA & $1,027,370$ & 35,402 & 3.33 & $1,210,674$ & 40,168 & 3.21 \\
\hline DD & 54,291 & 25,620 & 32.06 & 90,132 & 11,072 & 10.94 \\
\hline Total & $1,570,933$ & 158,819 & 9.18 & $1,991,162$ & 176,265 & 7.97 \\
\hline
\end{tabular}

Source: Computed from UEUS $(2009,2012)$

Theoretically, the basic-non basic ratio is expected to be one to one (1:1). This means that half of the total employment of the town thought to be in export industries and half in the local industries. There have been changes in the percentages of export employment in the towns considered in this study over the study period. Jimma, among the provincial towns, and Asayita, from the emerging regional capitals, have made significant increases in their proportion of export employment; though they didn't show changes in their three most basic functions. The bulk of the towns that made a slight increase in the proportion of the export employment over the study period include Addis 


\section{Changes in Urban Functional Structure in Ethiopia}

Ababa, together with Hawassa, Adama, Harar, Jigjiga and Gambella. However, most notably the towns like Dire Dawa, Assosa, Mekele, Gondar and Dessie experienced a substantial decrease in the export employment in the study period. While across all major towns, the export employment constituted only 8\% in the year 2012. Particularly, the export employment, for 2012, indicates that the capital, Addis Ababa, and the capitals of leading regions have relatively lower proportion of their total employment in the export sector while the figure is relatively higher for the provincial capitals and that of emerging regions (See Table 4.4). As could be seen from Table 4.4, larger urban centers tend to have higher sheer number of export base employment over the period considered.

In connection with the above discussion, Figure 4.1 presents the export employment change and multiplier for major urban centers included in this study over the study period.

One, in every six workers, is employed in export for Jimma town and about 10\% for Hawassa in the year 2009. In the same year, for Dessie, Mekelle, Adama, Bahir Dar and Harar towns, the proportion of basic employment is ranging between 5 to $10 \%$ of the total employment and for the remaining it is insignificant being less than $5 \%$ from the total.

However, in the year 2012, for Dessie, Mekele and Hawassa, the export employment is about 10\% of the total. But, for Dire Dawa, Bahir Dar, Adama, Jimma and Assosa, it ranges between 5 to $7 \%$ and for the remaining urban centers, the export employment is less than 5\% (see Figure 4.1). 
Changes in Urban Functional Structure in Ethiopia

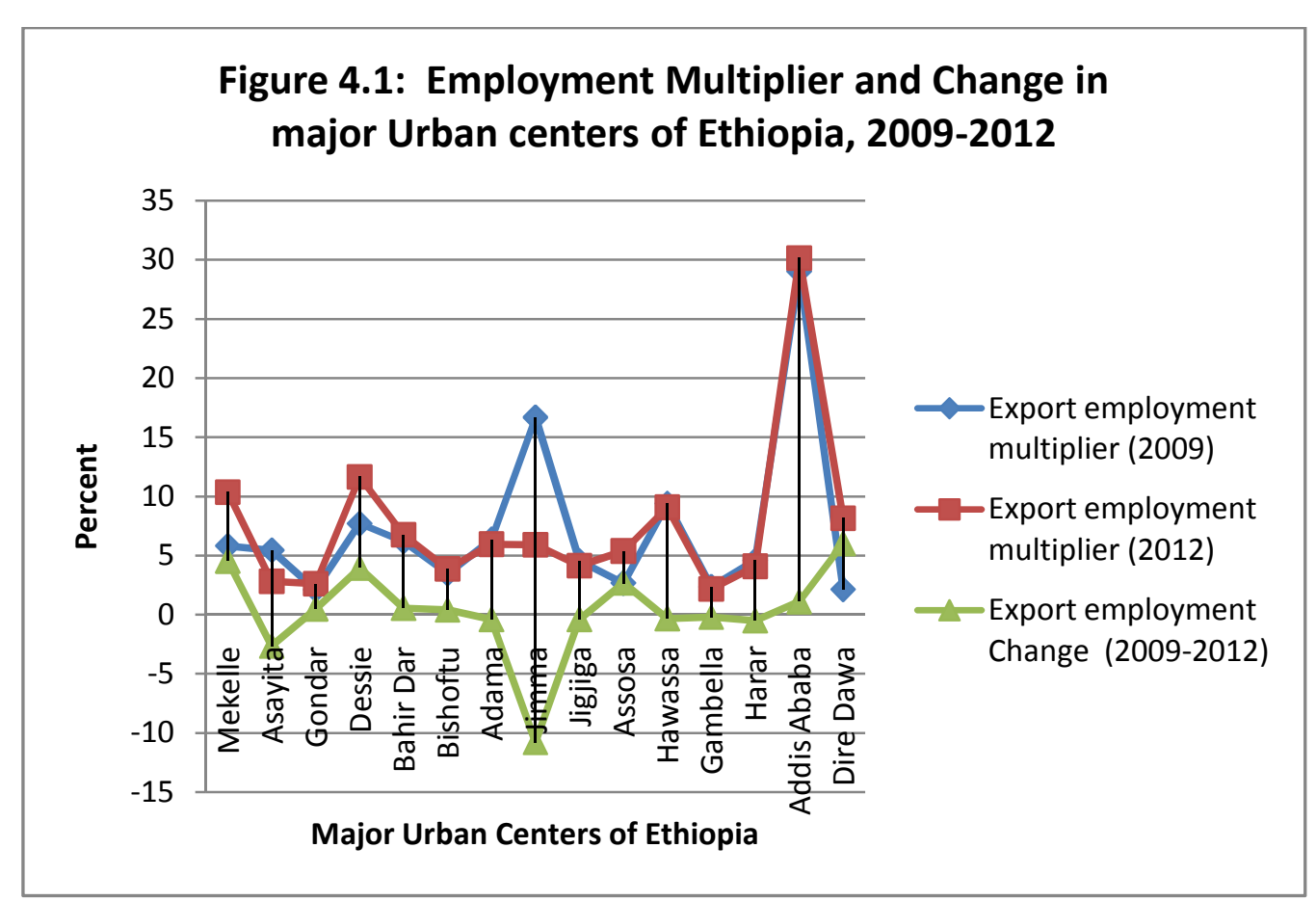

Source: Computed from UEUS $(2009,2012)$

An attempt was made to identify the changes in export employment multiplier. Some towns have made positive change pointing the increase in basic employment whereas others have negative export employment multiplier revealing the increase in local employment over the study period. Accordingly, towns such as Dire Dawa, Mekele, Dessie, Assosa, Addis Ababa, Bahir Dar, Gondar and Bishoftu, have positive export employment multipliers from 6 to $0 \%$ respectively. Positive export employment multipliers for these towns suggest that there is an increase in export employment in proportion to the total employment increase. Whereas substantial decrease has been observed in Jimma , Asayita, Harar, Adama, Jigjiga, Hawassa and Gambella respectively in their increasing order. This suggests that for these towns there is a decline in the basic employment in proportion to the increase in total employment but increase in local employment. However, this does not necessarily mean that there a negative absolute change basic employment. In absolute terms, except Dessie, Bishoftu, Assosa and Dire Dawa, all the rest have positive change implying their basic employment increased from 2009 to 2012. 
Changes in Urban Functional Structure in Ethiopia

\subsection{Shift share growth of Manufacturing and Construction}

\subsubsection{Shift share of growth in manufacturing in major urban centers}

Though the extent varies; all towns are impacted by the national growth component over the study period. Accordingly, the national growth effect of the manufacturing employment has revealed that, the capital, Addis Ababa, has more than $2 / 3^{\text {rd }}$ of the total impact growth followed by Adama (10\%), Bishoftu (6\%), Dire Dawa (6\%), Hawassa (5\%) growth due to national growth effects respectively. This reveals that the employment growth in the manufacturing sector nationally has positively influenced each town; even though the influence is higher for the large towns. The implication is that the respective growth in the manufacturing sector for each town is simply due to the growth at the national level in the sector. Table 4.5, presents the shift share decomposition manufacturing employment over the study period.

Table 4.5: Shift Share growth of manufacturing sector in major urban centers, 2009-2012

\begin{tabular}{lcccc}
\hline $\begin{array}{l}\text { Major } \\
\text { Towns }\end{array}$ & $\begin{array}{l}\text { National Growth } \\
\text { effect }(\boldsymbol{\%})\end{array}$ & $\begin{array}{c}\text { Industry Mix } \\
\text { effect }(\boldsymbol{\%})\end{array}$ & $\begin{array}{l}\text { Competitive Share } \\
\text { effect }(\boldsymbol{\%})\end{array}$ & $\begin{array}{c}\text { Total } \\
\text { Shift }(\boldsymbol{\%})\end{array}$ \\
\hline Mekelle & 2.99 & -0.95 & 41.28 & 43.32 \\
Asayita & 0.26 & -0.08 & -0.12 & 0.06 \\
Gondar & 4.08 & -1.29 & 8.51 & 11.31 \\
Dessie & 4.26 & -1.35 & -4.8 & -1.89 \\
Bahir Dar & 6.2 & -1.96 & 4.61 & 8.85 \\
Bishoftu & 5.78 & -1.83 & 1.04 & 4.99 \\
Adama & 10.46 & -3.31 & -4.95 & 2.19 \\
Jimma & 3.33 & -1.05 & -2.45 & -0.18 \\
Jigjiga & 1.21 & -0.38 & 0.63 & 1.45 \\
Assosa & 0.38 & -0.12 & 1.82 & 2.08 \\
Hawassa & 4.53 & -1.43 & 13.87 & 16.97 \\
Gambella & 0.39 & -0.12 & 1.08 & 1.34 \\
Harar & 3.65 & -1.15 & -0.7 & 1.79 \\
Addis Ababa & 111.53 & -35.29 & -74.8 & 1.43 \\
Dire Dawa & 5.7 & -1.81 & 2.37 & 6.27 \\
Total & 164.75 & -52.13 & -12.62 & 100.00 \\
\hline
\end{tabular}

Source: Based on computation from UEUS $(2009,2012)$

EJBE Vol. 4 No. 2/2014 


\section{Changes in Urban Functional Structure in Ethiopia}

As could be seen from Table 4.5, the IM effect for each town is negative. This implies that employment in manufacturing in each town did not grow above the national growth average. However, the CS of towns indicates that some towns are more competitive in manufacturing employment than others. For instance, in Mekele, from $43 \%$ total growth in employment, $41 \%$ is accounted for its competitiveness, in Hawassa, from $17 \%$ growth, $14 \%$ is due to competitive advantage, in Gondar, from $11 \%$ growth, $9 \%$ is because of local competitiveness. This suggests that these towns are likely to capture a larger share of the future employment growth in the manufacturing sector than others. However, Addis Ababa, Dessie, Harar \& Asayita have low competitive shares effects respectively which mean they will not capture more employment in this sector in the future. Conversely, the total change is negative for Dessie and Jimma towns owing to their respective competitive share \& industry effects which further suggest that the sector will not be important in terms of employing more workers in the future.

\subsubsection{Shift share growth of the construction employment in major urban centers}

The construction employment tends to be the booming industry in Ethiopia. This could be seen from its IM and CS components of the SSA. Table 4.6, presents the shift share decomposition of the construction employment over the study period. 
Changes in Urban Functional Structure in Ethiopia

\begin{tabular}{lcccc}
\multicolumn{5}{c}{ Table 4.6: Shift Share growth of construction sector in major urban } \\
centers, 2009-2012 \\
\hline Major Towns & $\begin{array}{c}\text { National Growth } \\
\text { Effect (\%) }\end{array}$ & $\begin{array}{l}\text { Industry Mix } \\
\text { Effect (\%) }\end{array}$ & $\begin{array}{c}\text { Competitive } \\
\text { Share Effect (\%) }\end{array}$ & $\begin{array}{c}\text { Total Shift } \\
(\boldsymbol{\%})\end{array}$ \\
\hline Mekelle & 3.00 & 0.32 & 14.56 & 17.87 \\
Asayita & 0.11 & 0.01 & 1.64 & 1.76 \\
Gondar & 3.33 & 0.35 & 0.75 & 4.44 \\
Dessie & 2.84 & 0.30 & -3.55 & -0.41 \\
Bahir Dar & 6.26 & 0.66 & 0.70 & 7.62 \\
Bishoftu & 3.11 & 0.33 & -3.11 & 0.33 \\
Adama & 6.62 & 0.70 & -16.24 & -8.92 \\
Jimma & 3.73 & 0.40 & -0.66 & 3.47 \\
Jigjiga & 1.61 & 0.17 & 0.65 & 2.43 \\
Assosa & 0.49 & 0.05 & 1.78 & 2.33 \\
Hawassa & 4.82 & 0.51 & 3.44 & 8.77 \\
Gambella & 0.67 & 0.07 & 0.22 & 0.97 \\
Harar & 2.08 & 0.22 & -0.83 & 1.46 \\
Addis Ababa & 52.26 & 5.54 & 2.79 & 60.59 \\
Dire Dawa & 5.27 & 0.56 & -8.55 & -2.72 \\
Total & 96.19 & 10.20 & -6.39 & 100.00 \\
\hline
\end{tabular}

Source: Based on computation from UEUS $(2009,2012)$

As could be seen from Table 4.6, the larger urban centers have the greatest share of the NG effect over the study period in the construction employment. Accordingly, Addis Ababa was impacted by more than half of the national NG effect (52\%), Adama (7\%), Bahir Dar (6\%), Dire Dawa (5\%) and Hawassa $(5 \%)$ respectively.

Unlike the manufacturing employment, the IM effect of the construction employment is found to be positive for all towns considered in this study. The capital Addis Ababa is contributing more than half (6\%) of the total (10\%) and the others having less than one percent each. This implies that the growth in the manufacturing employment is partly due its industry mix effect.

As in Table 4.6, the CS effect reveals that of the total growth of $18 \%$, about $15 \%$ is due to CS effect in Mekele \& for Hawassa, from nine per cent, it is about three per cent. Whereas, Adama, Dire Dawa, Dessie, \& Bishoftu are less 
competitive in the construction employment. This is because the competitive share component ranges from $-16 \%$ for Adama to -3 per cent for Bishoftu revealing the total growth occurred in them is due to NG and IM effects.

The total shift component of the construction employment has indicated that the capital Addis Ababa caters lion's share (61\%) of the total (100\%), followed by Mekele (18\%), Hawassa (9\%), Bahir Dar (8\%) between 2009 and 2012. However, Adama (-9\%), Dire Dawa (-3\%) and Dessie (-0.41\%) have revealed a decline in the construction employment between the years considered.

\section{Conclusion and Implications}

It has been observed from this study that the urban centers of Ethiopia are becoming multifunctional/functionally diversified. It is evident from the analysis that the larger the size of the population, the higher the tendency for urban centers to be multifunctional. However, the revealed problem of most urban centers is the relative position of the transformative industries' employment (secondary economic activities) based on LQ analysis. In most of all towns considered in this study, the extractive activities, social services, distributive activities and public administration and defense services play a major role as basic employers. Among, the secondary industries, the construction sector employment appears to be booming in the towns of leading and emerging regions alike.

In most cases dynamism has been observed in the fact that a sector which appeared the first ranked basic employer of a town never maintained its position next time. This is an indication that there are other sectors which are competing to become the basic employer of the towns considered in the study period. This is mainly the evidence that indicates the towns are becoming more of multifunctional.

For all major towns it is the local employment which has grown; not the export employment mainly in terms of percentage proportion. However, the export employment had a multiplier effect in the local employment, to some degree, in many of the major urban centers. Some towns of the leading regions like Mekele and Hawassa have better competitive advantage in the manufacturing, 


\section{Changes in Urban Functional Structure in Ethiopia}

construction and others more than other towns which, in turn, indicating better regional competitiveness.

Therefore, the implication of the economic base and shift share analysis could be discussed as follows. First, particularly for monitoring the urban economic/employment change study should be made on a continuous basis for specific urban centers which this paper did not address. Therefore, a separate and timely study using the same or mix of methods, for each and every medium and large urban center is needed for better monitoring of urban economic growth in Ethiopia. Second, the growth of secondary economic activities is low in most urban centers; though theoretically expected to drive the growth of the urban economy. Therefore, more efforts need to be made to foster the growth of this sector probably by increasing the competitiveness of towns in attracting the transformative sector. Last, the unclassified other social, community and personal service activities appear to be among the major economic bases of many urban centers studied. Therefore, probably reclassification maybe required to understand the sectors that employ large number of urban labour force. 
Changes in Urban Functional Structure in Ethiopia

\section{References}

Carter, H .1995. The Study of Urban Geography (4 ${ }^{\text {th }}$ Ed.), London: Arnold.

Chan, Y.2011. Location Theory and Decision Analysis, $2^{\text {nd }}$ Edition, Berlin: Springer.

CSA. 2009. Statistical Report on the 2009 Urban Employment Unemployment Survey, Statistical Bulletin, 469,Addis Ababa: Central Statistical Agency 2012. Statistical Report on the 2012 Urban Employment Unemployment Survey, Statistical Bulletin, 555, Addis Ababa: Central Statistical Agency

Dinc, M. 2002. Regional and Local Economic Analysis Tools, World Bank Institute, The World Bank.

Domanski, B \& Gwosdz, K.2010. Multiplier Effects on Local and Regional Development, Quaestiones Geographicae, 29 (2): Adam Mickiewicz University Press

Edwards, M. 2007. Regional and Urban Economics and Economic Development: Theory and Methods. New York: Taylor and Francis.

Huang, W.1977. A Study of Economic Base, Industrial Specialization and Diversification: The Case of Taiwan, Bulletin of the Institute of Ethnology, Academia Sinica, No 43: Springer.

Hustedde,R. Shaffer, R. \& Pulver, G.1993. Community Economic Analysis, Revised Edition, University of Wisconsin, Madison, Wisconsin

Isard, W.1960. Methods of Regional Analysis: An Introduction to Regional Science, Cambridge: MIT Press.

Kaizhong, Y.1998. Basic Features and Trends of the Economic bases of Beijing, Chinese Geographical Science, Vol. 9, No.1: Science Press. MoFED .2007. Plan for Accelerated and Sustainable Development to end Poverty (2005/6-2009/10): Plan for Urban Development and Urban Good Governance, FDRE, December 2007, Addis Ababa Mulligan,G .2008. A New Short Cut Method for Estimating Economic Base Multipliers, Regional Science Policy and Practice, Vol. 1, No.1. Oxford: Blackwell Publishing.

Nelson, H .1955. A Service Classification of American Cities, Economic Geography, Vol. 31, No. 3, Clark University, http://www.jstor.org/stable/142045. Retrieved June 10, 2013. 
Changes in Urban Functional Structure in Ethiopia

Pacione, M. 2009. Urban Geography: Global perspective, $3^{\text {rd }}$ Edition. London: Rutledge.

Paraskevopoulos, C.1974. Regional growth patterns in Canadian manufacturing industry: An Application of the Shift Share Analysis, Canadian Journal of Economics, VII, No. 1, JSTOR.

Ping, R. \& Hui, M. 2012. Quantitative Economic Analysis of the Industrial structure of Coastal City of Shandong Province, International Journal of Engineering and Manufacturing, MECS, http://www.mecs- press.net/ijem, Retrieved June 15, 2013

Quinetero, J. 2007. Regional Economic Development: An Economic Base Study and Shift Share Analysis of Hays County, Texas, Applied Research Project, Master Thesis of Public Administration, Texas University.

Solomon Mulugeta. 2008. The Economic Bases of Ethiopian Urban Centers, Journal of Ethiopian Studies, Vol.XLI, No. 1-2, June- December 2008.

Roberts, B, Stimson, J, Stough, R. 2006. Regional Economic Development: Analysis and Planning Strategy ( $2^{\text {nd }}$ Ed.) Berlin: Springer. 